P-ISSN: 2774-4574; E-ISSN: 2774-4582

TRILOGI, 2(3), September-Desember 2021 (332-341) @2021 Lembaga Penerbitan, Penelitian, dan Pengabdian kepada Masyarakat (LP3M) Universitas Nurul Jadid Paiton Probolinggo

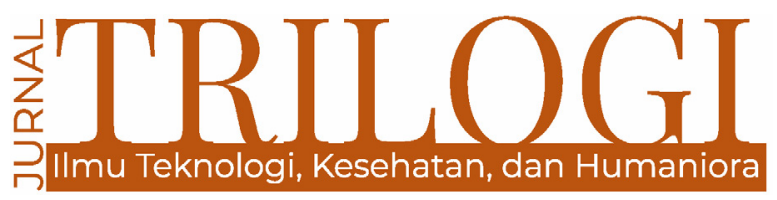

\title{
STRATEGI OPTIMALISASI PERAN WALI MURID UNTUK MENINGKATKAN MINAT BELAJAR SISWA DI MASA PANDEMI
}

\section{Muhammad Ainul Yaqin}

Universitas Nurul Jadid, Probolinggo

masainulyaqin@gmail.com

\section{Mustain Romli}

Universitas Nurul Jadid, Probolinggo

mustainromli.unuja@gmail.com

\section{Zainul Ilyas}

Universitas Nurul Jadid, Probolinggo

zainulilyas1996@gmail.com

\begin{abstract}
In the era of COVID-19 pandemic, teaching and learning process which was taught face-to-face, now has to switch to work from home (online). It makes students in each institution experience changes and have to get used to the nuances of different learning process. It raises its own problems that result in disrupted learning. It makes students feel bored and has an impact on decreasing learning interest. This research is intended to examine the problems that occur in learning process during the pandemic era in a comprehensive and straightforward manner by optimizing the process of education through the role of parents to increase student interest in learning. This research uses a descriptive qualitative method that focuses on describing all problems as well as finding solutions. The instruments used in data collections are interview and observation. Based on the results and discussion in the study, it was found that there were several obstacles experienced by institutions and parents in overseeing online learning, such as limitations in accessing the internet due to the lack of data and not having a cell phone. In addition, it was also found that the roles and efforts of parents is very essensial, such as providing mentoring or guidance one after another, and reviewing the learning outcomes from teachers after online learning. So that both of them complement each other through the efforts that are applied. That way, learning remains in a good position and students can still learn well and can grow their learning interest.
\end{abstract}

Keywords: parrents; learning Interest; pandemic 


\begin{abstract}
Abstrak
Pasca mewabahnya pandemi covid-19. Pendidikan yang semula pembelajarannya dilakukan secara tatap muka di sekolah, kini harus beralih pada sistem jarak jauh atau daring (dalam jaringan). Hal itu tentu membuat para siswa di setiap lembaga mengalami perubahan dan membiasakan diri kembali dengan nuansa pembelajaran yang berbeda. Tak jarang memunculkan problematika tersendiri yang mengakibatkan pembelajaran terganggu. Alhasil membuat para peserta didik kurang bersemangat dan berdampak pada penurunan minat belajar. Penelitian ini dimaksudkan untuk menelaah lebih lanjut mengenai permasalahan yang terjadi selama pembelajaran di masa pandemi secara komprehensif dan lugas. Membuka tabir strategis optimalisasi alur pendidikan di masa pandemi melalui peran wali murid untuk meningkatkan minat belajar siswa. Dengan menggunakan metode kualitatif deskriptif yang fokus menjabarkan seluruh permasalahan sekaligus menemukan solusinya. Dimana pengumpulan datanya menggunakan instrumen wawancara dan observasi. Berdasarkan hasil dan pembahasan dalam penelitian ditemukan bahwa terdapat beberapa kendala yang dialami oleh lembaga dan wali murid dalam pembelajaran daring. Seperti keterbatasan dalam mengakses internet disebabkan kurangnya paket data dan tidak memiliki telepon seluler. Selain itu juga ditemukan bahwa peran dan upaya orang tua yang begitu esensi, seperti melakukan pendampingan atau bimbingan secara silih berganti, mempelajari kembali hasil belajar dari guru setelah daring melalui pendampingan orang tua. Sehingga keduanya saling membenahi atau mengisi satu sama lain melalui upaya-upaya yang diterapkan. Dengan begitu, pembelajaran tetap dalam posisi yang baik dan peserta didik tetap bisa belajar dengan baik serta dapat menumbuhkan minat belajarnya.
\end{abstract}

Katakunci: wali murid; minat belajar; pandemi

\section{Pendahuluan}

Munculnya wabah pandemi COVID-19 (Corona Virus Desease 19) telah merubah pola kehidupan di seluruh belahan dunia. Virus tersebut diperkirakan muncul pada tanggal 30 Desember 2019, tepatnya di kota Wuhan Tiongkok. Covid-19 merupakan sejenis penyakit menular yang disebabkan karena mudah berpindah dari satu manusia ke manusia lain. Biasanya gejala yang dirasakan seseorang yang terkontaminasi virus corona akan mengalami rasa lelah, demam dan batuk kering. Siapapun dapat tertular virus covid-19. sebab yang menjadi trajektori penularan virus tersebut dari individu ke individu lain melalui percikan ketika batuk dan bersin, percikan terhirup langsung, bernapas atau berbicara, menyentuh tangan orang sakit secara langsung, dan menyentuh mata, hidung serta mulut secara langsung. (Bender, 2020).

Hal tersebut tentunya sangat berpengaruh terhadap jalannya proses pembelajaran di sekolah. Berdasarkan surat edaran (Kementerian Pendidikan dan Kebudayaan, 2020) Nomor 4 Tahun 2020 tentang Kebijakan Pelaksanaan Pendidikan Dalam Masa Darurat Penyebaran Corona Virus Desease 19 (Covid-19) melalui Surat Edaran Sekretaris Jenderal No. 15 Tahun 2020 tentang Pedoman Pelaksanaan Belajar dari Rumah selama Darurat Bencana (Covid-19)
Tujuan diberlakukannya belajar dari rumah yaitu untuk: (1) Melindungi warga satuan pendidikan dari dampak buruk COVID-19 (2) Mencegah penyebaran dan penularan COVID-19 di satuan pendidikan (3) Memastikan pemenuhan dukungan psikososial bagi pendidik, peserta didik dan orang tua atau wali. (4) Memastikan pemenuhan hak anak untuk mendapatkan layanan pendidikan selama darurat COVID-19 Setelah diterbitkan surat edaran tersebut maka proses pembelajaran mulai dari tingkat Perguruan Tinggi sampai PAUD harus dilaksanakan dari rumah. Tidak terkecuali untuk jenjang Sekolah Dasar dan Madrasah Ibtidaiyah juga melakukan proses pembelajaran dalam jaringan daring dari rumah.

Penyebarannya yang begitu cepat, membuat beberapa sektor di negara-negara dunia mengalami kelumpuhan. Salah satunya di sektor pendidikan, pendidikan mengalami penurunan yang drastis. Mulai dari cara belajar murid dengan guru dan lembaga, dan cara mengajar guru kepada peserta didik. Hal ini tentu mengundang kesulitan bagi lembaga dalam melakukan proses belajar mengajar yang berbeda dari biasanya (tatap muka). Maka kesulitan tersebut akan memberikan dampak yang serius bagi lembaga dalam melakukan aktivitas pembelajaran seharihari. Secara umum dapat dibedakan menjadi dua macam yakni sebagai tantangan (penemuan hal baru) atau sebagai sumber kemerosotan. 
Jika sebagai tantangan, maka lembaga akan betul-betul berupaya menyalurkan segala kinerjanya dengan semaksimal mungkin. Guna untuk mencari celah jalan keluar menemukan sistem yang pas dalam mendukung proses pembelajaran. Meskipun terbilang sulit karena dampak pandemi. Di sisi lain, adanya tantangan juga akan melatih ketangkasan lembaga dalam mengelola segala sesuatu yang sudah ada pada lembaga tersebut. Sehingga lembaga tak perlu menghilangkan apa-apa yang sudah menjadi ciri khas lembaga. Lembaga hanya butuh penemuan baru yang merangkul metode pembelajaran sekaligus ciri khas yang dimiliki tersebut. Dan ketika hal baru tersebut dapat diraih oleh lembaga, maka bukan hanya soal keeksisan yang didapat. Tentu juga apresiasi diri yang telah sukses melewati berbagai rintangan selama pandemi berlangsung.

Jika sebagai sumber kemunduran, maka tentu lembaga akan mengalami degradasi dari berbagai sisi. Seluruh aktivitas pembelajaran kian amburadul, arah pendidikan yang di citacitakan lembaga akan mengalami stagnan atau tidak ada perubahan, justru yang terjadi adalah keterpurukan. Maka ketika kemunduran semakin berlanjut, bisa dipastikan lembaga atau instansi menerima konsekuensi yang amat berat, contohnya kurangnya minat belajar siswa dan turunnya progresifitas lembaga dalam mengawal pembelajaran. Namun kemunduran tersebut tidak semerta-merta terjadi, terdapat sebab-akibat yang dilalui oleh lembaga. Tergantung bagaimana cara lembaga memandang keterbatasan (akibat pandemi), apakah dijadikan sebagai peluang yang cerah atau harus kandas dengan menyerah begitu saja.

Meskipun sejatinya, kesulitan dalam melakukan pembelajaran bukan hanya ada pada instansi terkait. Tetapi juga ada pada siswa dan wali murid (orangtua). Kesulitan tersebut hadir sebab belum adanya kesiapan atau kebiasaan mengaktualisasikan pembelajaran dari rumah. Ketidaksiapan untuk merealisasikan pembelajaran daring umumnya muncul karena fasilitas yang belum memadai, kurangnya dukungan atau bantuan kepada lembaga, siswa dan wali murid. Belum lagi masalah keuangan lembaga yang mulai menipis. Sehingga tidak jarang, ada lembaga yang keteteran dalam melakukan pembelajaran online tersebut. Begitu juga dengan siswa dan wali murid. Di sisi lain, ketidakbiasaan melangsungkan pembelajaran daring, baik itu lembaga, siswa dan wali murid.
Biasanya terdapat hal-hal ketidaknyamanan pada saat dilancarkannya pembelajaran dari rumah. Seperti tidak bisa berkomunikasi secara langsung dengan guru, gugup untuk bertanya melalui media internet yang disediakan, tidak bisa bersosialisasi secara langsung dengan teman kelas dan lain-lain. Sehingga akan memunculkan kurangnya kepuasan dalam proses pembelajaran. hadirnya virus covid-19 begitu mengganggu aktivitas pembelajaran. Tetapi mau tidak mau tetap harus dilakukan dan diikuti secara saksama. Karena pendidikan tetaplah sangat penting untuk kehidupan negara dan dunia.

Pendidikan merupakan aset penting bangsa sehing bangsa bisa berkembang dan maju. Pendidikan yang baik dapat dijadikan proyeksi akan masa depan bangsa tersebut. Oleh karenanya, anak adalah generasi bangsa yang wajib tumbuh dan berkembang dengan baik. Yakni ditumbuh kembangkan dengan pendidikan yang bermutu (Hasan Mansur Nst, 2008). Proses kegiatan belajar mengajar akan berhasil dengan baik serta mencapai tujuan pembelajaran apabila ada kerja sama antara orang tua, siswa, dan lembaga. Dengan demikian diharapkan akan berdampak pada peningkatan prestasi belajar siswa sekaligus minat belajar. Untuk itu penting sekali sekali adanya berbagai usaha kegiatan kerja sama antara orang tua, siswa dan lembaga secara terprogram. Tujuan adanya pendidikan secara spesifik untuk dapat mengembangkan kemampuan yang ada dalam diri tiap individu yang meliputi kognitif (pengetahuan), keagamaan (spritual), sikap (afektif), dan keterampilan (psikomotorik). Kemudian kemampuan-kemampuan tersebut dapat dilaksanakan dalam kehidupan sehari-hari dan menjadikan anak berguna bagi bangsa dan negara.

Merespon adanya hal tersebut (Covid-19), pemerintah pusat maupun daerah dengan sigap mengeluarkan kebijakan berupa pembelajaran daring (dalam jaringan) atau online yang sebelumnya berbasis tatap muka secara langsung. Kebijakan tersebut dicita-citakan dapat meminimalisir sekaligus memutus mata rantai angka korban akibat Covid-19. Sebab kehadiran virus tersebut tidak hanya menyerang kalangan orang-orang dewasa dan lansia (lanjut usia). Tetapi juga menyerang keberadaan anak kecil, remaja, bahkan bayi sekalipun. Tentu ketika dibiarkan akan mengundang keprihatinan yang serius serta bisa saja menambah angka kematian yang berlarut-larut. 
Konsekuensi adanya penutupan lembaga yang dialihkan ke pembelajaran dari rumah sesuai arahan pemerintah. Maka keberadaan lembaga, orang tua atau wali murid, siswa, tentu juga guru harus berpindah ke sistem online atau istilah lainnya belajar dalam jaringan. Meskipun menyadari bahwa adanya distingsi pada saluran teknologi pembelajaran dan bervariannya problem yang dihadapi orang tua. Kementrian Pendidikan dan Kebudayaan Republik Indonesia menyatakan secara tegas terkait kebijakan pembelajaran daring (Wahyono \& Husamah, 2020).

Pada awalnya, implikasi virus corona adalah di bidang ekonomi. Kemudian kini dirasakan juga oleh dunia pendidikan. Beberapa kebijakan sudah dikeluarkan oleh banyak negara termasuk Indonesia yang mengambil inisiatif meliburkan aktivitas pendidikan tanpa terkecuali. Sehingga membuat pemerintah dan lembaga harus menghadirkan jalan lain untuk tetap bisa melangsungkan proses pendidikan di suatu lembaga pendidikan. (Dewi, 2020). Meskipun, tidak semua lembaga, pengajar (dosen dan guru), peserta didik (siswa dan mahasiswa) mahir dalam menggunakan teknologi internet atau media sosial sebagai media pembelajaran selama pandemi masih berlangsung. Belum lagi masalah kuota internet, sinyal atau jaringan dan yang lebih memprihatinkan ialah kendala tidak mempunyai alat pendukung pembelajaran daring seperti: telepon seluler, laptop dan lainnya. Hal itu mengakibatkan munculnya problem tersendiri yang dapat membelenggu dan menjadi penyebab utama peserta didik tidak dapat mengikuti proses belajar secara daring. Bahkan mengakibatkan peserta didik harus putus sekolah.

Di sisi lain, yang menjadi titik urgen selama proses pembelajaran daring atau jarak jauh ini ialah peran aktif wali murid guna tetap menjaga sekaligus menumbuhkan minat belajar peserta didik. Pendampingan wali murid diharapkan dapat menuntun dan sebagai bentuk kesadaran wali murid atau orang tua siswa dalam mengarahkan setiap anaknya mengikuti pembelajaran dengan baik. Orang tua sebagai guru pertama bagi anak tetap terealisasikan dengan optimal. Memastikan secara sungguh-sungguh bahwa peserta didik atau anak sudah melakukan pembelajaran secara baik dan benar. Maka di sinilah peran aktif wali murid sangat diperhitungkan eksistensinya. Selain menambah wawasan baru dalam diri tiap wali murid juga mendukung upaya tetap terlaksananya pembelajaran dengan efektif dan kondusif. Meskipun sistem yang ditempuh berbeda dari sebelumnya yakni sistem daring.

Dalam upaya menjaga dan menumbuhkan minat belajar. Tentu membutuhkan yang namanya motivasi belajar, khususnya motivasi dari wali murid itu sendiri. Implikasi adanya motivasi belajar yang diberikan oleh wali murid atau orang tua, selain menambah gairah semangat belajar juga meningkatkan kedekatan anak dengan orang tua (secara emosional). Menurut (Hasbullah, 2001) bahwa dukungan orang tua sangatlah berdampak pada motivasi belajar anak. Senada dengan teori (Hamalik, 2020), bahwa motivasi adalah keinginan, dorongan, kebutuhan dan daya atau kekuatan yang bisa menggerakkan kepribadian seseorang.

Motivasi merupakan dorongan psikologis untuk melakukan sebuah tindakan dalam mencapai tujuan yang telah ditetapkan (Badaruddin, 2015). Motivasi belajar erat kaitannya dengan prestasi yang diperoleh tiap individu, motivasi belajar bisa dikatakan sebagai upaya dorongan yang hadir baik dari dalam diri individu maupun dari luar diri personal untuk diimplementasikan dalam mencapai keberhasilan belajar. Adanya motivasi belajar yang tinggi akan membuat siswa menjadi semangat dalam belajar sehingga akan dengan mudah mendapatkan atau meraih hasil belajar yang maksimal. Sebaliknya motivasi yang rendah akan mengundang siswa kehilangan semangat dan stimulus untuk belajar. Maka sejatinya motivasi harus ditanamkan dalam diri siswa sejak dini mungkin, agar siswa merasa senang dalam mengikuti setiap proses pembelajaran tanpa adanya tekanan dan paksaan. Motivasi belajar bukan sekedar dorongan bagi siswa untuk mengetahui proses pembelajaran. Lebih dari itu juga penting untuk memahami hasil dari pembelajaran yang telah dilakukan.

Jika berjalan terus menerus (continue) maka bisa dipastikan bawa pembelajaran dan minat belajar yang menjadi cita-cita lembaga akan benar-benar berwujud nyata. Namun yang perlu diperhatikan adalah kemampuan ekstra wali murid dalam mendukung proses belajar dan memberikan motivasi tersebut. Bisa dikatakan akan menambah beban orang tua, terutama Ibu yang sehariharinya mengerjakan pekeraan rumah tangga. Dibutuhkan kesabaran dan ketelatenan dalam mengawal peserta didik atau anaknya. Beberapa penelitian mengatakan bahwa kedekatan seorang Ibu lebih besar kepada anak daripada kedekatan seorang Ayah. Hal tersebut dibuktikan dengan adanya sifat 'keibuan' yang dimiliki seorang ibu yang membuat anak lebih dekat nalurinya kepada 
ibu. Maka di sinilah urgensi wali murid khususnya Ibu ketika mendampingi alur pembelajaran peserta didik dan seorang anak.

Penulisan artikel jurnal ini bertujuan untuk memberikan pemahaman dan memaparkan secara universal tentang bagaimana optimalisasi peran wali murid untuk meningkatkan minat belajar siswa di masa pandemi. Sehingga wali murid atau orang tua dapatlah lebih paham lagi dalam menumbuhkan minat belajar anaknya dari rumah. Penelitian ini berfokus pada permasalahan optimalisasi peran wali murid untuk meningkatkan minat belajar siswa di masa pandemi.

\section{Metode}

Metode penelitian kualitatif adalah metode metode penelitian yang berlandaskan pada filsafat postpositivisme atau kebenaran yang didasarkan pada esensi atau bersifat holistik, digunakan untuk meneliti pada kondisi obyek yang alamiah, (sebagai lawannya adalah eksperimen) di mana peneliti adalah instrument kunci, teknik pengumpulan data dilakukan secara triangulasi (gabungan), analisis data bersifat induktif/kualitatif, dan hasil penelitian kualitatif lebih menekankan makna daripada generalisasi (Prof. Dr. Sugiyono, 2015). Metode penelitian merupakan cara dan prosedur yang sistematis dan terorganisasi untuk menyelidiki suatu masalah tertentu dengan maksud mendapatkan informasi untuk digunakan sebagai solusi atas masalah tersebut (Silalahi, 2009).

Adapun metode yang diterapkan dalam penelitian ini adalah metode kualitatif deskriptif yang berfokus mendeskripsikan seluruh permasalahan sekaligus menemukan solusinya secara rinci dan lugas. Mengenai pengumpulan data, penelitian ini berbasis instrumen wawancara dan observasi. Objek penelitian berpusat pada segenap wali murid MI NURUL MUN'IM (yang berjumlah dua orang), lembaga terkait (kepala sekolah) dan peserta didik (berjumlah satu orang) yang semuanya memberikan informasi secara akurat. Teknik analisis dalam penelitian ini adalah Analysis Interactive yang terdiri dari data Collection (pengumpulan data), data reduction (reduksi data), data display (penyajian data), data conclutions (penarikan kesimpulan).

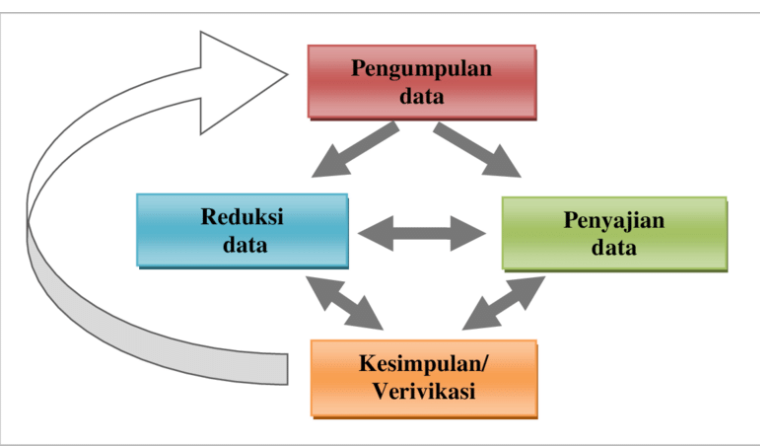

Gambar 1. Teknik analisis data

Wawancara adalah teknik pengumpulan data yang digunakan oleh peneliti ketika ingin melakukan studi pendahuluan untuk menemukan permasalahan yang harus diteliti, dan juga apabila peneliti ingin mengetahui hal-hal dari responden yang lebih mendalam dan jumla respondennya sedikit/kecil (Prof. Dr. Sugiyono, 2015). Menurut (Sutrisno Hadi, 1986) bahwa anggapan yang perlu dipegang oleh peneliti dalam menggunakan metode wawancara adalah sebagai berikut:

1. Subyek (responden) adalah orang yang paling paham terhadap dirinya sendiri.

2. Bahwa yang dikatakan oleh subyek kepada peneliti adalah benar dan dapat dipercaya.

3. Iinterpretasi subyek mengenai pertanyaanpertanyaan yang diajukan peneliti kepadanya adalah sama dengan apa yang dimaksudkan oleh peneliti.

Observasi merupakan suatu proses yang kompeks, suatu proses yang tersusun dari pelbagai proses biologis dan psikologis. Di antara yang terpenting adalah proses-proses pengamatan dan ingatan (Sutrisno Hadi, 1986). Teknik pengumpulan data berupa observasi digunakan apabila penelitian berkenaan dengan perilaku manusia, proses kerja, gejala-gejala alam dan bila responden yang diamati tidak terlalu besar.

\section{Hasil dan Pembahasan}

Sebagai sekolah atau instansi yang mewadahi proses terjadinya pendidikan. Sudah sebuah kewajiban untuk menciptakan minat belajar tinggi kepada para siswa-siswinya. Agar peserta didik tetap sejahtera dan merasa nyaman dalam melakoni pembelajaran sehari-hari. Sehingga, tak ada ketimpangan antara pendidikan yang disuguhkan oleh lembaga dan peserta didik yang menuntut atau mencari ilmu. Selain itu, 
upaya untuk tetap menjaga minat belajar siswa yang dilakukan oleh lembaga di masa pandemi. Akan memberikan paradigma baru dan ketahanan dalam mengelola pendidikan di masa pandemi. Lembaga akan mampu tetap eksis dan bersaing di tengah merebaknya wabah COVID-19. Citra baik dari masyarakat bahkan pemerintahan akan hadir sebagai apresiasi ketangguhan lembaga dan inovatif lembaga dalam merawat dan menumbuhkan pendidikan di tengah-tengah pandemi, khususnya dalam menciptakan minat belajar yang tinggi. Lembaga yang sukses bertarung dengan pandemi bukan hanya menyelamatkan eksistensi lembaga itu sendiri. Tetapi juga menyelamatkan para siswa dan pendidikan sesuai cita-cita bangsa Indonesia.

Terutama peran orang tua berupa dorongan atau stimulus dalam mendukung kegiatan belajar dari rumah yang dikombinasikan dengan keterlibatan guru dalam memberikan materi atau pengajaran sangat berarti untuk melangsungkan pendidikan anak. Sebab orang tua adalah guru pertama dari anak-anaknya. Orang tua tidak hanya sebagai sosok pemenuh kebutuhan anak secara material saja. Kebutuhan immaterial juga arus mempunyai porsi yang lebih besar. Tanpa adanya peran orang tua kepada anak dalam proses menjalani pembelajaran lebih-lebih pembelajaran daring akan memunculkan dampak buruk. Di mana pendidikan yang diperoleh anak selamadi bangku pendidikan tidak akan begitu menyatu dalam kemasyarakatan atau sosial. Padahal jika ditelaah lebih dalam, kemampuan akademis yang mencakup sisi karakter atau bahkan iwa dan raga. Semata-mata bukanlah tugas seorang guru saja. Peran orang tua sangatlah penting dan sentral.

Anak yang tidak mendapatkan pendampingan atau perhatian dari orang tua dalam pendidikannya dapat menjadikan anak kurang atau tidak berminat dalam melakukan pembelajaran yang sudah disediakan oleh lembaga. Berbanding terbalik dengan anak yang mendapatkan perhatian orang tua, apalagi perhatiannya berpusat pada pembelajaran dari rumah. Anak akan merasa lebih giat da bersemangat saat orang tuanya turut ikut andil memotivasi dengan tulus. Sehingga anak akan merasa bahwa tidak hanya dirinya yang ingin berprestasi, tetapi orang tuanya juga memiliki keinginan yang sama. Alhasil proses pembelajaran yang dilalui oleh anak atau peserta didik benarbenar baik dan maksimal (Alsi R. Valeza, 2017).

Orang tua patut mengetahui terhadap peran dan tanggung jawabnya dalam proses pendidikan anaknya. Karena adanya keterkaitan orang tua dalam memberikan pendidikan serta meninjau perkembangan anak akan berpengaruh besar terhadap pola minat belajarnya lebih-lebih dalam prestasi belajar anak tersebut. Untuk itu orang tua harus mengetahui bagaimana perkembangan akademik dan perilaku anaknya baik di sekolah maupun di luar sekolah. Maka dari itu, orang tua dan pihak sekolah (guru) harus saling menjalin kerja sama yang baik. Ketika anak berada di lingkungan keluarga ataupun lingkungan di luar sekolah, maka yang bertanggung jawab mengawasi anak adalah orang tua.

Orang tua sangat strategis keberadaannya dalam memberikan pendidikan kepada anak atau siswa. Bukan hanya memberikan tatanan pendidikan, tetapi orang tua juga harus menyodorkan segala perhatian dan kasih sayang terhadap anak-anaknya, sebab hubungan yang baik serta akrab antara orang tua dan anak, akan mengakibatkan adanya bergairah, termotivasi dan lebih percaya diri dalam melakoni belajar tentu juga minat belajarnya. Perhatian, kasih sayang serta motivasi orang tua merupakan asupan anak yang harus diwadahi sebagai modal utama mentalnya untuk menambah stamina minat belajarnya semakin tinggi hingga meraih prestasi di sekolah bahkan di masyarakat.

Pada dasarnya, aktivitas atau perbuatan yang diamalkan setiap orang didasari pada kecenderungan dan keinginan atau minat. Definisi minat adalah keterampilan, pengetahuan, ketekunan, fokus, perhatian, dan rasa ketertarikan atau rasa suka. Minat menduduki posisi dasar yang urgen bagi individu dalam melaksanakan kegiatan dengan baik. Minat tidak hanya berdampak pada tingkah laku individu, akan tetapi bisa mendukung seseorang melaksanakan atau memperoleh sesuatu dengan baik. Keluarga mempunyai peranan penting dalam mendukung minat belajar anak di rumah maupun di sekolah. Apabila keluarga khususnya orang tua mampu merangsang, membimbing dan mendorong kegiatan belajar anaknya. Hal itu akan membuat diri anak memiliki minat belajar yang tinggi. Maka sebaliknya, jika orang tua tidak peduli terhadap kegiatan belajar anak. Anak akan mengalami dan memiliki yang yang rendah. Sehingga sulit untuk meraih prestasi di sekolah dan mempunyai minat belajar yang tinggi.

Berdasarkan data dari hasil wawancara dan observasi yang penulis lakukan selama penelitian berlangsung. Beragam tanggapan hadir yang dilatarbelakangi munculnya pandemi covid-19 yang mengganggu alur pendidikan, terutama 
pembelajaran yang kini diganti dengan sistem daring (dalam jaringan) atau belajar dari rumah. Membuat lembaga, siswa terutama orang tua yang saat ini memiliki tugas tambahan harus mengondisikan diri mendampingi anaknya dalam mengikuti pembelajaran dari rumah.

Melihat kondisi atau lingkungan di sekolah dan di rumah berbeda. Tentu pembelajaran yang terjadi di sekolah dan di rumah juga berbeda. Hal itu tampak bagaimana ketika belajar di rumah selalu terganggu dengan teman-teman bermainnya anak atau peserta didik. Sehingga kefokusan dalam mengikuti pembelajaran kian menurun. Belum lagi pembelajaran daring yang mayoritas menggunakan telepon seluler untuk mengikutinya. Tidak jarang membuat para siswasiswi lebih fokus ke telepon selulernya dari pada buku belajarnya. Belum lagi di sisi kedisiplinan yang menurun dikarenakan tidak lagi diawasi oleh guru seperti masih ketika pembelajaran tatap muka di sekolah.

Tentu ketika segala permasalahan di atas dibiarkan tanpa penanggulangan lebih lanjut. Maka pembelajaran melangalami stagnan dan mengakibatkan peserta didik kehilangan minat belajarnya. Tidak lain, di sinilah peran orang tua sangat diharapkan. Ketika orang tua menyadari akan peranannya mendampingi dan mengawasi anaknya. Bukan suatu kemustahilan, sehingga orang tua akan memaksimalkan segala upayanya untuk kemajuan minat belajar anak. Berdasarkan data dari hasil penelitian yang peneliti lakukan adalah sebagai berikut:

\section{a. Orang Tua}

Upaya Orang Tua Meningkatkan Minat Belajar Anak di Masa Pandemi, di antaranya;

1. Melakukan pendampingan atau bimbingan secara silih berganti.

Bimbingan adalah aktivitas yang dilaksanakan oleh individu. Guna membantu seseorang yang sedang kesulitan. Sehingga, harapannya orang tersebut bisa menjalaninya dengan penuh kesadaran dan kesiapan (Sucipto dan Raflis, 2000). Maka dalam hal ini orang tua terus melakukan bimbingan yang berkesinambungan. Maka minat belajar anak akan merasa didukung oleh orang tuanya. Hal ini dilakukan oleh salah satu wali murid sebagai upaya tetap menjaga dan menumbuhkan minat belajar anaknya. Ketika orang tua perempuan (ibu) berbenturan dengan aktivitas lain. Maka di situlah peran orang tua laki-laki (bapak) dibutuhkan untuk mendukung proses belajar anak. Kedua orang tua tetap menyadari pentingnya mendampingi anak selama pembelajaran daring berlangsung adalah kunci dasar terlaksananya pendampingan tersebut. Orang tua melakukan pengawasan bukan hanya untuk sekedar mengawasi tetapi juga turut ikut serta belajar bersama anaknya. Sehingga anak merasa aman dan nyaman ketika melakukan pembelajaran daring. Dan naluri antara anak dan orang tua pun semakin erat. Maka kemudian, minat belajar itu akan tumbuh perlahan disamping dukungan orang tua yang tetap terus dilanjutkan.

Pengawasan yang dilakukan oleh orang tua tentu tidak bersifat pasif. Tetapi justru harus aktif, saling berbagi pendapat dengan anak, menanyakan sesuatu yang tidak dimengerti oleh anak, mengarahkan anak di setiap mengikuti pembelajarannya dan menjadi motivator yang baik bagi anak. Orang tua memberikan dorongan tentang pentingnya belajar. Dengan harapan bisa meningkatkan minat belajar anak. Sehingga anak merasa membutuhkan apa yang dianjurkan oleh orang tuanya (Sucipto dan Raflis, 2000). Itu semua merupakan wujud konkret upaya orang tua yang ingin betulbetul mendampingi anaknya, tidak setengahsetengah. Bahkan boleh jadi justru orang tua ikut bertanya kepada guru yang mengajar (tidak secara terus menerus). Anak akan semakin bersemangat, minat belajarnya yang sebelumnya pudar akan bertambah dengan adanya orang tua disampingnya.

2. Mempelajari kembali hasil belajar dari guru setelah daring.

Hal tersebut diupayakan oleh salah satu orang tua murid sebagai bentuk kesadaran dan kepedulian kepada anak atau menjadi fasilitator tambahan bagi anak dalam melakukan pembelajaran. Dalam belajar mengajar orang tua menyediakan berbagai fasilitas seperti media, alat peraga, termasuk menentukan berbagai jalan untuk mendapatkan fasilitas tertentu dalam menunjang program anak. Orang tua sebagai fasilitator juga turut mempengaruhi tingkat minat belajar yang ingin dicapai anak (Sucipto dan Raflis, 2000). Sebab tidak semua anak akan langsung mengerti setelah mengikuti pembelajaran daring. Ditambah 
lagi penjelasan guru yang hanya sebatas pesan suara. Tidak jarang akan membuat anak kebingungan dan akhirnya merasa jenuh untuk kembali mengikuti pembelajaran daring selanjutnya. Maka dampaknya juga akan menurunkan minat belajar anak, di mana semestinya anak haruslah tetap pada posisi yang mapan yakni minat belajarnya yang tetap terjaga, bahkan terus tumbuh hari demi hari.

Keputusan orang tua untuk kembali mengulas hasil belajar anak setelah mengikuti belajar daring adalah tindakan yang tepat. Karena anak akan benar-benar matang dan akan benar-benar paham apa yang sebelumnya tidak dimengerti akan dimengerti. Begitu juga dengan orang tua, ia bisa lebih berinteraksi secara lebih mendalam dengan anaknya. Lambat laun orang tua juga bisa mengetahui bakat dan minat dari anaknya. Orang tua berperan sebagai pendidik sebab dalam pekerjaannya tidak hanya mengajar, tetapi juga melatih keterampilan anak (Sudirman A,M, 2011). Maka dalam hal ini orang tua juga bertanggungjawab menemukan bakat dan minat anak melalui keaktifan orang tua dalam mengawal anaknya. Sehingga anak akan memperoleh prestasi belajar secara lebih optimal.

Para orang tua siswa mesti memahami bahwa meski di rumah. Anak tetaplah harus konsentrasi pada proses pembelajaran yang sedang berlangsung. Di sinilah dukungan dan pengertian para orang tua sangat dibutuhkan keberadaannya. Dari sini juga akan diketahui bagaimana seharusnya orang tua memberikan pendidikan kepada anaknya sekaligus memahami apa saja tugas para guru, sehingga bisa dijadikan pegangan atau rujukan dalam mengawal pembelajaran anak. Karena itu, orang tua juga perlu mendampingi bagaimana anak-anaknya melakukan proses belajar (Praherdiono, 2020).

Orang tua sebagai pendidik bagi anakanak nya sendiri. Fungsinya ialah mempertanggungjawabkan, melindungi, mengasuh, mengasah, dan mengasihi. Menjadi orang tua berarti ada kesediaan untuk melaksanakan fungsi yang menjadi pelaksana dan penjaga amanah yang dipercayakan kepadanya (Rosdiana Abu Bakar, 2012). Orang tua di sini harus sepenuhnya siap membimbing anaknya setiap saat, tidak terkecuali dalam membimbing anaknya mengikuti pembelajaran di masa pandemi yang berbasis daring (dalam jaringan). Maka hal tersebut membuat anak semakin meningkat dalam belajar, begitu juga minat belajarnya. Dan dampaknya adalah mencuatnya prestasi anak baik yang bersifat tampak (seperti prestasi menjuarai perlombaan mata pelajaran tertentu) atau yang bersifat tidak tampak (seperti meningkatnya keingintahuan anak terhadap setiap sesuatu).

\section{b. Lembaga}

Demi mempertahankan eksistensi Lembaga dan keberadaan pendidikan di Lembaga tersebut. Membuat setiap Lembaga harus bergerak cepat demi menangani pembelajaran yang saat ini terhalang pandemi virus covid-19. Sesuai arahan dari pemerintah yang saat itu juga mengeluarkan surat instruksi memberlakukan pembelajaran jarak jauh atau dari rumah berbasis online. Di sinilah Lembaga kembali mendapat tantangan bagaimana agar pembelajaran daring yang ditetapkan oleh Lembaga bisa mendukung proses belajar siswa atau peserta didik. Serta juga bisa menjaga minat belajar bahkan menambah minat belajar para siswanya. Upaya-upaya tersebut antara lain:

a) Menyegerakan penggunaan pembelajaran daring sesuai arahan biro pendidikan dan pemerintah pusat.

Hal itu dilakukan sebagai usaha tetap menjaga dan meningkatkan minat belajar peserta didik, agar tidak terlalu lama terbelenggu pandemi dan terbuang nya waktu belajar.

b) Memilih menggunakan sistem voice di aplikasi WhatsApp tanpa kirim vidio.

Hal tersebut sesuai dengan hadirnya problem-problem yang disuarakan oleh banyak wali murid. Seperti keluhan di kuota internet. Maka dari itu lembaga menginginkan pembelajaran daring yang bersifat kontinuitas. Sehingga memilih sistem voice yang diharapkan bisa meminimalisir kuota atau data.

c) Setiap bulan, lembaga mengadakan rapat evaluasi terkait masukan dari wali murid.

Hal ini dilakukan sebagai bentuk kepedulian dan kepekaan terhadap suasana pembelajaran para siswa selama pandemi. Tujuannya adalah meningkatkan pembelajaran menjadi lebih baik dari hari ke hari 
dan tidak ingin melunturkan minat belajar siswanya yang sudah terhalang pandemi. Tetapi Lembaga terus berupaya menemukan sesuatu yang baru untuk dipersembahkan kepada segenap siswa dan wali murid.

d) Setiap bulan setelah rapat bulanan, wali kelas menyambangi rumah-rumah para peserta didik.

Hal tersebut dijalankan dalam rangka membina para peserta didik dan wali murid agar tidak terlalu berlarut-larut membiarkan anaknya yang sehari-harinya hanya diisi dengan aktivitas yang dapat menggangu proses belajarnya. Seperti keseringan bermain tiktok dan terlalu banyak menyimpan aplikasi game. Sebab itulah lembaga terus melakukan inovasi berupa perhatian lebih seorang guru, khususnya wali kelas kepada para siswa dan wali murid. Guna proses pembelajaran yang sudah berjalan bisa tetap kondusif dan peserta didik tetap bisa menumbuhkan minat belajarnya. Sehingga harapan lembaga adalah terciptanya suasana pembelajaran melalui kerja sama antara lembaga dan wali murid bisa terealisasi dengan tepat sasaran.

e) Lembaga melakukan pemberian data dan pinjaman telepon seluler kepada wali murid yang tidak memilikinya.

Upaya itu dilakukan semata-mata untuk memaksimalkan proses pembelajaran daring selama pandemi. Sehingga anak didik tetap bisa belajar dengan selayaknya dan tetap bisa menumbuhkan minat belajarnya seperti temen-temen yang lainnya.

f) Memberikan pelayanan yang terbaik.

Di sinilah keberanian lembaga diuji. Lembaga tetap memiliki keteguhan penuh terhadap pelayanan yang akan diberikan kepada murid dan wali murid yaitu berupa pelayanan terbaik. Baik itu dari segi pembelajaran, sarana dan kebutuhan tindak lanjut ketika peserta didiknya sudah lulus dari lembaga tersebut. Padahal diasa pandemi, tentu keuangan dan kebutuhan bisa saja lebih besar pengeluarannya. Akan tetapi pelayanan masih tetap menjadi prioritas utama. Meski pandemi menghantui. Sehingga harapannya adalah masyarakat sekitar memiliki kesadaran tinggi bahwa pembelajaran tetap harus dilanjutkan dengan sebaik mungkin. Dan peserta didik bisa tetap melanjutkan proses belajarnya dan meningkatkan minat belajarnya. Di mana segala kebutuhan masih tetap diwadahi lembaga.

Upaya-upaya di atas yang dilakukan oleh lembaga sebagai upaya optimal atau terbaik demi tetap menciptakan pembelajaran dengan nuansanuansa yang berbeda. Meski pandemi masih tetap ada. Lembaga mampu memberikan pembelajaran secara totalitas. Hal tersebut terbukti bagaimana peran dan upaya guru dalam mengajar yang semangatnya luar biasa meski terkendala pandemi covid-19. Pandemi tidak menyurutkan semangat mengajar guru membimbing anak didiknya meski lewat pesan suara. Benar-benar memberikan totalitas yang melancarkan tanggungjawab besar menjadi seorang guru. Hal itu juga didukung bagaimana semangat guru datang ke lembaga setiap harinya. Meski hanya mengisi satu mata pelajaran secara tatap muka bagi yang berdomisili di pondok dan pembelajaran daring bagi yang berdomisli di rumah. Sehingga yang terjadi adalah Lembaga diakui keberadaannya dalam melaksanakan pembelajaran jarak jauh yang dinilai bagus dan efektif.

\section{Kesimpulan}

Sebagai upaya memutus rantai penyebaran wabah covid-19. Pemerintah pusat sekaligus daerah dengan progresif mengeluarkan surat instruksi berupa peralihan atau pergantian sistem pembelajaran. Yang awalnya menggunakan sistem tatap muka secara langsung kini beralih ke sistem daring atau belajar dari rumah. Hal tersebut memungkinkan munculnya berbagai permasalahan yang dialami oleh wali murid, lembaga dan siswa itu sendiri. Mulai dari kendala di akses jaringan yang disebabkan oleh tidak muncukupinya data internet dan fasilitas lain yang tidak memadai seperti tidak adanya telepon seluler. Munculnya permasalahan demi permasalahan di atas membuat pembelajaran yang awalnya kondusif, harus mengalami pematangan kembali. Terbukti bahwa peserta didik mengalami perubahan pada cara belajarnya dan cara mengajar guru kepada murid. Sehingga dari itu semua, proses pembelajaran selama masa pandemi covid-19 membutuhkan dukungan lebih yang diharapkan dapat membantu menumbuhkan minat belajar siswa. Yakni melalui peran orang tua dan lembaga. Orang tua dan lembaga memiliki peranan penting dalam mengontrol, mengawasi, dan mendampingi pembelajaran anak. Khususnya 
orang tua, bisa dikatakan pendidikan saat ini mayoritas kesuksesannya berada pada upaya orang tua dalam memerhatikan dan mengarahkan cara belajar anak. Sehingga diharapkan minat belajar yang ada dalam diri anak terus tumbuh tanpa harus terhalangi keberadaan covid-19. Dengan demikian dampaknya ialah pada pertumbuhan prestasi siswa yang semakin meningkat.

\section{Referensi}

Cahyanti, Nika \& Rita Kusumah. (2020). Peran Orang Tua dalam Menerapkan Pembelajaran di Rumah Saat Pandemi Covid 19. Jurnal Golden Age, Universitas Hamzanwadi. Vol 04, 152-159.

Hayati, (2020). Peran Orang Tua dalam Meningkatkan Motivasi Belajar Anak Dengan Sistem Daring pada Masa Pandemi di Desa Depokrejo, Kebumen. Journal of Institut Agama Islam Negeri Ponorogo. Vol 27, 23-32.

Juliani, (2018). Kerja Sama Orang Tua Dan Guru dalam Meningkatkan Prestasi Belajar Siswa di Min 7 Kota Medan Kecamatan Medan Denai, Medan Tahun Ajaran 2018/2019. Skripsi. Fakultas IImu Tarbiyah Dan Keguruan. Pendidikan Guru Madrasah Ibtidaiyah. Universitas Islam Negeri Sumatera Utara Medan.

Kementerian Pendidikan dan Kebudayaan, R I. (2020), Surat Edaran No 4 Tahun 2020 Tentang Pelaksanaan Kebijakan Pendidikan Dalam Masa Darurat Penyebaran Virus Corona Disease Covid 19, Jakarta.

Khalimah. (2020). Peran Orang Tua dalam Pembelajaran Daring di Mi Darul Ulum Pedurungan KoTa Semarang Tahun Pelajaran 2020/2021. Skripsi. Fakultas Tarbiyah dan Ilmu Keguruan. Pendidikan Guru Madrasah Ibtidaiyah. Institut Agama Islam Negeri (Iain) Salatiga.
Lya, dkk. (2020). Peran Orang Tua dalam Meningkatkan Minat Belajar Peserta Didik di Rumah Pada Mata Pelajaran Pendidikan Agama Islam Sd Negeri 1 Sidorenggo Ampelgading. Jurnal Pendidikan Islam. Vol 05, 70-77.

Praherdiono, Henry. (2020). Implementasi Pembelajaran di Era dan Pasca Pandemi Covid-19. Malang: CV. Seribu Bintang.

Prof. Dr. Sugiyono. (2015). Metode Penelitian Kuantitatif, Kualitatif, dan R\&D, Alfabeta: Bandung.

Rapita, Ritonga \& Siregar, (2021). Analisis Minat Belajar Siswa dalam Pembelajaran Daring Pada Masa Pandemi Covid-19 di Desa Ujung Batu Barus. Jurnal MathEdu (Mathematic Education Jounal). Vol 04, 88-96.

Rosdiana Abu Bakar. (2012). Pendidikan Suatu Pengantar. Bandung: Citapustaka Media.

Safitri. (2020). Peran Orangtua dalam Meningkatkan Minat Belajar Anak Pada Pembelajaran Online Di Sd Negeri 5 Metro Pusat. Skripsi. Fakultas dan Ilmu Keguruan. Jurusan Pendidikan Guru Madrasah Ibtidaiyah. Institut Agama Islam Negeri (IAIN) Metro. Metro Lampung.

Sardiman A,M. (2011). Interaksi dan Motivasi Belajar Mengajar . Jakarta: CV Rajawali.

Sucipto dan Raflis. (2000). Profesi Keorangtuaan. Jakarta: Rineka Cipta.

Syachtiyani, Wulan \& Trisnawati. (2021). Analisis Motivasi Belajar dan Hasil Belajar Siswa di Masa Pandemi Covid-19. Jurnal IImiah Pendidikan. Vol 2, 91-101.

Wardhani, Yustika \& Krisnani. (2020). Optimalisasi Peran Pengawasan Orang Tua dalam Pelaksanaan Sekolah Online di Masa Pandemi Covid-19. Prosiding Penelitian \& Pengabdian Kepada Masyarakat. Vol 07, 48-59.

Yunitasari, Ria \& Hanifah, (2020). Pengaruh Pembelajaran Daring terhadap Minat Belajar Siswa pada Masa Covid-19. Jurnal IImu Pendidikan. Vol 2, 232-242. 